\title{
Antoni Mironowicz
}

Katedra Historii Europy Środkowo-Wschodniej

Wydział Humanistyczny, Uniwersytet w Białymstoku

\section{SPECYFIKA POGRANICZA POLSKO-BIALORUSKIEGO}

Pojęcie pogranicza polsko-białoruskiego jest terminem kulturowym, zmiennym i nieprecyzyjnym. Wywodzi się z rozumienia podziałów etnicznych i narodowych w Europie, jest przenoszone na różne terytoria państw w zależności od zmieniającej się sytuacji politycznej. Granice etniczne na pograniczu polsko-białoruskim podlegały nieznacznym przesunięciom w ciągu stuleci w odróżnieniu od ciągłych zmian politycznych i państwowych. W XIX w. termin pogranicza polsko-białoruskiego umownie odnoszono do dzisiejszego Podlasia, Grodzieńszczyzny i Polesia. Wielowiekowa przynależność obu narodów do jednego organizmu państwowego sprawiła, że pogranicze polsko-białoruskie występowało na terenie innych obszarów, takich jak Nowogródczyzna czy Wileńszczyzna. We współczesnych realiach prawno-państwowych pogranicze polsko-białoruskie jest traktowane jako terytorium znajdujące się po obu stronach granicy, obejmujące tereny Białostocczyzny, Grodzieńszczyzny i Obwodu Brzeskiego.

Przestrzeń pogranicza polsko-białoruskiego miała swoją specyfikę historyczną, gospodarczą, kulturową i religijną. Cechą tego regionu jest historyczna wspólnota losów obu narodów. Przez wiele stuleci obszary te należały do tego samego organizmu państwowego. Tereny znajdujące się po obu stronach granicy przynależne były do księstw ruskich, Wielkiego Księstwa Litewskiego, Rzeczypospolitej, zaś po jej upadku weszły do Prus, a następnie do Rosji. W Imperium Rosyjskim białoruskie elementy narodowe były traktowane przez władze carskie na równi z polskimi. Wspólne losy terenów dzisiejszego pogranicza w II Rzeczypospolitej i latach powojennych uformowały specyficzny obraz wzajemnych relacji i oddziaływań. Jakże dramatyczne i tragiczne zarazem były wybory polityczne elity ówczesnego społeczeństwa kresowego. Jego przedstawiciel Bronisław Taraszkiewicz, wychowany w środowisku wielokulturowym, autor pierwszej gramatyki białoruskiej, tłumacz Pana Tadeusza Adama Mickiewicza na język białoruski, członek białoruskich i polskich organizacji narodowych, poseł do sejmu polskiego, więzień w Rzeczypospolitej za białoruski nacjonalizm, został stracony w Związku Radzieckim w 1937 r. z tego samego powodu ${ }^{1}$. Owo wewnętrzne roz-

${ }^{1}$ A. Bergman, Sprawy białoruskie w II Rzeczypospolitej, Warszawa 1984, s. 142-165. 
darcie i doświadczenia z okresu międzywojennego spowodowały, że część inteligencji kresowej wolała odwoływać się do obywatelstwa Wielkiego Księstwa Litewskiego aniżeli utożsamiać się z jakąkolwiek ideą narodową.

Białoruskie elity polityczne słabo akcentowały swe dążenia do niepodległego bytu narodowego. Społeczeństwo pogranicza w XIX w. bardziej hołdowało tradycjom archaicznym niż postulowało utworzenie samodzielnego państwa. $\mathrm{W}$ ich mniemaniu ideologie narodowe naruszały tradycję historyczną i były traktowane jako element obcy, niszczący dotychczasowe układy społeczne. W tak zróżnicowanym etnicznie areale trudno było zaszczepić hasła narodowe, tożsame z jednym dominującym Kościołem. Nawet wśród jednej grupy etnicznej wybór wyznania i narodu był niejednokrotnie różny. Ród Szeptyckich, zasłużony dla polskiej i ukraińskiej idei narodowej, jest tego najlepszym przykładem. Podobnie było z przedstawicielami białoruskiego rodu Iwanowskich z Wilna, którzy odegrali istotną rolę w białoruskim, polskim i litewskim ruchu narodowym.

\section{Styk dwóch wielkich tradycji}

Na pograniczu polsko-białoruskim doszło do styku dwóch wielkich tradycji chrześcijańskich. Spotkanie dwóch ośrodków cywilizacyjnych bizantyjsko-słowiańskiego i łacińskiego doprowadziło do wytworzenia na przestrzeni wieków specyficznych norm kulturowych i form współżycia społecznego. Podstawowy składnik tych norm stanowiło i stanowi nadal wyznanie. Europa Środkowo-Wschodnia schrystianizowana już w średniowieczu przez Kościół bizantyjski i łaciński była miejscem przenikania się różnych tradycji chrześcijańskich. Gdy do tego dodamy bogactwo orientu wschodniego przywiezione przez Turków, Tatarów i Ormian, obraz kulturowo-wyznaniowy pogranicza polsko-białoruskiego stanie się jeszcze bardziej wielobarwny. Wiek XVI wzbogacił ową mozaikę wyznaniową o nowe grupy religijne powstałe pod wpływem reformacji. Obok głównych nurtów reformacyjnych - luteranizmu i kalwinizmu - ziemie zachodnie Wielkiego Księstwa Litewskiego stały się miejscem azylu anabaptystom niemieckim, antytrynitarzom włoskim, kwakrom angielskim i menonitom holenderskim. A przecież nie możemy zapominać o istniejącym od średniowiecza wpływie ludności żydowskiej na sytuację gospodarczą i kulturową miast owego pogranicza.

Powstaje w tym miejscu pytanie o rolę wyznania - rzymskokatolickiego, unickiego, prawosławnego - w określeniu przynależności narodowej mieszkańców pogranicza polsko-białoruskiego. Szukając odpowiedzi, należy zaznaczyć, że chrześcijaństwo wschodnie było stałym elementem życia religijnego w ponadtysiącletniej historii tej części Europy Wschodniej. W historii wielu narodów tego obszaru prawosławie stanowiło ich podstawową religię, fundamentalny element świadomości kształtujący rodzimą kulturę i tożsamość. Ono ostatecznie określiło krąg cywilizacyjno-kulturowy Białorusinów i Ukraińców. Późniejsze oddziały- 
wanie na te narody innych wyznań i Kościołów miało drugorzędne znaczenie. Podobną rolę w dziejach Polaków i Litwinów odegrał Kościół rzymskokatolicki. Poznanie pogranicza polsko-białoruskiego i roli poszczególnych wyznań w formowaniu świadomości narodowej jego mieszkańców ma fundamentalne znaczenie w zrozumieniu tożsamości religijno-kulturowej zamieszkałej tam społeczności.

\section{Tolerancja odmienności kulturowej i religijnej}

Pogranicze polsko-białoruskie może wnieść wiele cennych wartości do zjednoczonej Europy. Dziedzictwo historyczne tego obszaru ma również wiele chwalebnych kart - nie zawsze dostrzeganych. Wielonarodowa i wielowyznaniowa tradycja tego regionu stanowi namiastkę dawnej Rzeczypospolitej. Akceptacja innowierców na terenach pogranicza polsko-białoruskiego nie wynikała tylko z ich siły, ale z doktryny politycznej o potrzebie zagwarantowania pokoju wyznaniowego. W XVI w. zwolennicy reformacji powoływali się na tradycje zgodnego współżycia różnych wyznań na ziemiach litewsko-ruskich. Przypominano, że w państwie Jagiellonów oprócz katolików i prawosławnych można było spotkać mahometan i przedstawicieli wyznania mojżeszowego. Wzbogacenie owej mozaiki wyznaniowej o luteranów, kalwinów, antytrynitarzy, anabaptystów, arian, menonitów czy kwakrów było dla ówczesnych czymś naturalnym. Doświadczenia tolerancji z Wielkiego Księstwa Litewskiego wpłynęły w XVI w. na jej teoretyczny i faktyczny charakter w całej Rzeczypospolitej. W czasach kontrreformacji, tam gdzie nie można było zmusić prawosławnych do przyjęcia katolicyzmu, stawiano na nieunikniony kompromis, zapewniając im ograniczoną tolerancję. Nie odwoływano się do metod niemieckich lub francuskich z okresu wojny trzydziestoletniej czy nocy św. Bartłomieja. Nic też dziwnego, że na pograniczu polsko-białoruskim, Podlasiu i Polesiu, w XVII i XVIII w. zachowały się największe skupiska ludności prawosławnej na terenie Wielkiego Księstwa Litewskiego.

U źródeł polskiej tolerancji znajdowały się doświadczenia historyczne zgodnego współżycia wyznaniowego z pogranicza polsko-ruskiego za panowania ostatnich Piastów i Jagiellonów. Liczne alianse małżeńskie i stała obecność kultury prawosławnej w granicach państwa polskiego czyniła z prawosławia religię własną, a nie obcą. Wielowyznaniowa Rzeczpospolita była kontynuatorką wielkich osiągnięć polityki religijnej Wielkiego Księstwa Litewskiego. W Rzeczypospolitej powstał wówczas na szeroką skalę nowy model cywilizacji chrześcijańskiej, jakże odmienny od chrześcijaństwa krajów Europy Zachodniej i Wschodniej. Zasada tolerancji, a nie przymusu wyznaniowego, miała stać się podstawowym elementem polityki państwa ${ }^{2}$.

${ }^{2}$ A. Mironowicz, Specyfika tolerancji wyznaniowej na kresach wschodnich Rzeczypospolitej, [w:] Pogranicza etniczne w Europie. Harmonia i konflikty, red. K. Krzysztofek, A. Sadowski, Białystok 2001, s. 163-173. 
$\mathrm{Na}$ pograniczu polsko-białoruskim zasady zgodnego współżycia różnych grup wyznaniowych i narodowości miały szczególne znaczenie. Niejednokrotnie sejmiki z województw wschodnich domagały się od króla przestrzegania praw i wolności wyznaniowych. Szlachta zebrana na sejmiku słonimskim w maju $1632 \mathrm{r}$. uzależniała swój udział w elekcji króla od uregulowania spraw wyznaniowych. Ponadto, zobowiązywała posłów na sejm do czynienia starań ,żeby religije wszystkie, nabożeństwa kościelne uspokojone były"3. W Akademii Wileńskiej studiowali prawosławni i kalwini, a w prawosławnej Akademii Ostrogskiej nauki pobierali katolicy. Wspólne uczestniczenie w uroczystościach religijnych (pielgrzymowanie do miejsc świętych, udział w przyjęciach weselnych), często występujące na Kresach małżeństwa osób różnych wyznań spowodowały, że Piotr Skarga, jeden z największych orędowników kontrreformacji, piętnował tych katolików, którzy „zawierają małżeństwa $\mathrm{z}$ heretyczkami, prowadzą z różnowiercami rozmowy o wierze, na pogrzeby ich chodzą, sługi heretyki i urzędniki chowają, syny do szkół i ziem heretyckich posyłają"4. Osąd gorliwego jezuity potwierdza, że w tej części Rzeczypospolitej można było zaobserwować przejawy indyferentyzmu religijnego w społeczeństwie. Powstały też ponadwyznaniowe formy organizacji życia, w których szacunek do innowierczego sąsiada lub małżeństwa mieszane były czymś naturalnym.

Tolerancja wyznaniowa na pograniczu polsko-białoruskim łączyła się z problematyką o wiele szerszą aniżeli dobre współistnienie różnych wyznań. Swoboda publicznego wyrażania kultu oraz propagowania własnego wyznania wpłynęła na inne dziedziny życia publicznego i prywatnego. Dawała podstawę do otwierania się społeczeństwa ruskiego i polskiego na nowinki napływające z zagranicy. W przypadku pogranicza polsko-białoruskiego docierały one z zachodu, wschodu i południa. Nie można bowiem zapominać o istotnej roli kultury bizantyjskiej i wschodniego orientu, tak szeroko zakorzenionego w kulturze sarmackiej. Przykładem może tu być architektura i wystrój wewnętrzny świątyni Zwiastowania NMP w Supraślu czy wielowyznaniowy i wielokulturowych charakter Grodna i Wilna. W miastach pogranicza obok kościołów stałym elementem były cerkwie, zbory i synagogi. Wraz z otwartością religijną zmieniają się obyczaje i kultura tamtejszego społeczeństwa. Obserwujemy te zjawiska w literaturze, sztuce, postawach politycznych, mentalności następnych pokoleń. Zakorzeniona tradycja chrześcijaństwa wschodniego i zachodniego, wzbogacona o wpływy judaistyczne i orientalne, zakorzeniła się we wszystkich formach życia ludności ruskiej i wpłynęła na oblicze kulturowe obecnych mieszkańców Białostocczyzny, Grodzieńszczyzny, Wileńszczyzny i innych obszarów kresowych państwa ${ }^{5}$. Brak radykalnych

${ }^{3}$ A. Mironowicz, Prawostawie i unia za panowania Jana Kazimierza, Białystok 1997, s. 52.

${ }^{4}$ J. Tazbir, Specyfika polskiej tolerancji, [w:] Naród - Kościót - Kultura. Szkice z historii Polski, Lublin 1986, s. 63-65.

${ }^{5}$ A. Mironowicz, Tolerancja wyznaniowa na pograniczu polsko-białoruskim, [w:] Kościoły i związi wyznaniowe a świadomość narodowa mieszkańców pogranicza, red. A. Mironowicz, M. Ulanowski, Białystok 2007, s. 21-32. 
konfliktów wyznaniowych, które miały miejsce na innych terenach tego regionu Europy Środkowo-Wschodniej (Wołyń w II wojnie światowej), stanowi dobry przykład oddziaływania dawnej tradycji historycznej na współczesny wizerunek pogranicza polsko-białoruskiego. Dziedzictwo historyczne owego obszaru, zakorzenione w mentalności społeczeństwa po obu stronach granicy, może odgrywać znaczącą rolę w integracji Białorusi z Unią Europejską i być dobrym przykładem dla innych wschodnich sąsiadów.

\section{Przekaz tradycji kulturowej}

Ukształtowana przez stulecia specyficzna tolerancja wyznaniowa w województwach wschodnich Rzeczypospolitej wpłynęła na postawy mieszkającej tam ludności w XIX i XX w. Przyjęty tam model współistnienia innowierców, naruszany często przez zewnętrzne impulsy płynące z Warszawy czy Petersburga, pozwolił tamtejszemu społeczeństwu przetrwać najtrudniejsze momenty dziejowe. Istniejąca symbioza kultur i wyznań kształtowała jego oblicze. $Z$ jednej strony bardziej aniżeli gdzie indziej nastawionego patriotycznie, a z drugiej - kumulującego elementy kulturowe innych narodów.

Historyk, profesor Johan Rhode, zwracał uwagę na wpływ tolerancji wyznaniowej na postawy ludności dawnych Kresów Wschodnich podczas powstania styczniowego. „Nie było w Europie krajów, które by w XVI i I-szej połowie XVII w. praktykowały taką tolerancję w prawach religijnych i etniczno-narodowych, jak to czyniła Unia Polsko-Litewska. Uznawała ona sześć języków za urzędowe, a cztery wyznania dawały przykład idealnej niemal koegzystencji z judaizmem $\mathrm{i}$ islamem, dopóki kontrreformacja nie rozpoczęła walki z protestantyzmem i prawosławiem. Pamięć o tym pokojowym współżyciu była wciąż żywa w okresie operacji rosyjskiej w XIX w." Zapewne z tego powodu polskie powstania niepodległościowe na ziemiach białoruskich i litewskich zyskały poparcie miejscowej ludności.

Według wielu badaczy historii kultur pogranicza wielkość Adama Mickiewicza, Marka Chagalla, Stanisława Moniuszki czy Tadeusza Kościuszki wyrastała ze specyficznej kultury i tolerancji na dawnych Kresach Wschodnich. Dla tych wielkich postaci Kresy pozostaną małą ojczyzną, twórczym natchnieniem, sensem politycznych zmagań. Warto tu przywołać pogląd emigracyjnego mickiewiczologa, Symona Bragi, który w 1955 r. napisał: „Białoruskie elementy w Mickiewiczowskiej twórczości to nie tylko jakaś ich powierzchowna okrasa. To coś, co zrośnięte jest z nią organicznie i co jest od niej nieodłączne, coś, co tkwi w samych korzeniach jej twórczości. Chodzi tu o fakt całkiem naturalny u kogoś,

${ }^{6}$ Cyt. za: K. Okulicz, Białorusini, Litwini i Polacy w powstaniu styczniowym na Litwie Historycznej, „Zeszyty Historyczne” [Paryż] 1964, t. VII, s. 19. 
kto jak Mickiewicz na Białorusi urodził się i na niej wyrósł pod bezpośrednim wpływem tego, co składało się na byt i kulturę tamtejszego chłopstwa i drobnej szlachty”. I dalej ,[...] to nie kraj Wisły i Warty, a Niemna i Wilna okazywał się przyrodzoną i niewyczerpaną krynicą Mickiewiczowskiego poetyckiego talentu i natchnienia"?.

Adam Mickiewicz najdobitniej zamanifestował swoje przywiązanie do wielokulturowej tradycji nie tylko jako poeta. Jednym z najciekawszych wątków wykładów wygłoszonych przez poetę z katedry College de France było ukazanie dramatycznego procesu wypierania na terenach ziem wschodnich białoruszczyzny przez język polski. „Dola polszczyzny przed wiekiem XVI - zauważył Mickiewicz - okazała się jakże smutna i jakże bardzo pozostawała ona w tyle za ruszczyzną, będącą mową dworu i wojska, mową, w której pisano prawa i układano statuty! Podczas gdy tamta zdążyła się już posunąć w rozwoju, dialekt polski, jakkolwiek rozciągał się szeroko aż po Śląsk, nie miał bytu urzędowego i prawnego: Kościół go odepchnął, nie był dopuszczony do prawodawstwa. Bywały w języku polskim statuty i przywileje prowincjonalne, ale na ogół prawa kanoniczne i państwowe pisano po łacinie. Wkrótce role się odwróciły: Jakaż to - zapytywał Mickiewicz - siła wstrząsnęła narodowością polską i popchnęła ją ku ziemiom ruskim, wypierając narodowość i język ruski aż za Dniepr?” I odpowiada: „Siła ta nie wyrosła z polskiego gruntu, wypływała ona z bardzo daleka, była wynikiem zbiegu okoliczności i nie mających żadnego na pozór związku z dziejami Polski: oto Kościół wziął na siebie dzieło rozniesienia szeroko mowy polskiej, którą przedtem sam przez długi czas w Polsce przytłumiał"8.

Kultura pogranicza ukształtowała wielu polityków. Józef Piłsudski, zwracając się do Białorusinów w Mińsku 19 września 1919 r., podkreślał, że ,jest synem tej ziemi, co zebrani, i dlatego może lepiej rozumieć i odczuwać wszystkie biedy i nieszczęścia, które były jej udziałem"”. Z kolei zafascynowany Kresami bardziej nam współczesny pisarz Tadeusz Konwicki z sentymentem pisał o Białorusi: „Powinnaś się nazywać Dobroruś, powinnaś się nazywać Dobrą Ziemią Dobrych Ludzi. [...] Nie odebrałaś innym wolności, nie rabowałaś cudzej ziemi, nie mordowałaś zza sąsiedzkiej miedzy. Miałaś dla obcych szacunek i gościny kołacz, miałaś dla rabusiów ostatnią krowę i ostatnią kromkę żyznego chleba ze znakiem krzyża, miałaś dla nieszczęśliwych krwawiące serce i biedne niebieszczone życie do oddania. [...] Kiedy przypomnę białoruskie słowo, kiedy zawieje wiatr z północnego wschodu, kiedy zobaczę płócienną koszulę ze smutnym haftem, kiedy

${ }^{7}$ A. Mickiewicz, Dzieła, t. IX, Warszawa 1955; S. Braga, Mickiewicz i biełaruskaja płyń polskaje literatury, [w:] Z historyjaj na ,wy”. Artykuty, dakumenty, uspaminy, Mińsk 1994, s. 293-294; A. Mironowicz, Andrzej Kempfi w kręgu Mickiewiczowskich alborutheników, [w:] Wilno i Ziemia Mickiewiczowskiej Pamięci. Materiaty III Międzynarodowej Konferencji w Białymstoku, t. I: W kręgu spraw historycznych, red. E. Feliksiak, E. Konończuk, Białystok 2000, s. 377-385.

${ }^{8}$ A. Mickiewicz, Dzieła, t. IX.

${ }^{9}$ M. Brandys, Strażnik Królewskiego Grobu, Warszawa 1984, s. 5. 
usłyszę krzyk bólu bez skargi, zawsze żywiej uderzy mi serce, zawsze wyskoczy skądś ładna tęsknota, zawsze popłynie raptowny chłód nieokreślonych wyrzutów sumienia, poczucie współwiny i zawstydzenia"10. Konwicki nawiązywał w tym stwierdzeniu do polskiej wschodniej polityki, która podobnie jak wielkoruska, nie dostrzegała odmienności narodowej Białorusinów. Polonizacja ludności białoruskiej i traktowanie jej często jak obywateli drugiej kategorii było sprzeczne $\mathrm{z}$ dotychczasową tradycją wielokulturowej Rzeczypospolitej.

O specyfice pogranicza polsko-białoruskiego decydowała nie elitarna kultura polska, ale ludowa kultura białoruska, a nawet litewska, znacznie bardziej otwarta aniżeli kultura ludowa Słowian zachodnich. Kultura ta cechowała się, poza otwartością, skłonnością do przyswajania wpływów obcych: bizantyjskich, orientalnych, łacińskich. Na pograniczu polsko-białoruskim wyrosła ona z tradycji dawnej Rzeczypospolitej, posiadała bogate życie estetyczne i była z zasady bardziej tolerancyjna. Specyfika tolerancji na tych obszarach polegała na akceptowaniu odmienności i szacunku do tradycji kulturowych sąsiadów. Elity społeczeństwa białoruskiego, polonizując się, dawały impuls pozostałym grupom społecznym do szacunku wobec różnych wyznań i kultur. Nienawiść do innych narodów, wyrażana podczas powstań niepodległościowych, miała bardziej podtekst polityczny aniżeli etniczny czy wyznaniowy. Destabilizacja tradycyjnej tolerancji wyznaniowej następowała zawsze pod wpływem czynników zewnętrznych.

Bez znajomości powyższych faktów trudno jest zrozumieć specyfikę pogranicza polsko-białoruskiego. Pojawiają się tam, nieznane na taką skalę w innych regionach, zjawiska tożsamości i samoidentyfikacji społecznej. Kultura oparta na specyficznej obrzędowości jest tam sama w sobie nośnikiem wielkiego ładunku emocjonalnego. Analiza tego zjawiska na pograniczu polsko-białoruskim pozwala zrozumieć ewolucję zachodzących tam procesów społeczno-ustrojowych, kulturowych i politycznych, które doprowadziły na początku XX w. do samoidentyfikacji narodowej.

\section{Perspektywy rozwojowe pogranicza polsko-białoruskiego}

Przemiany polityczno-ustrojowe dokonane w ostatniej dekadzie XX i na początku XXI w. w Europie Wschodniej stawiają nowe wezwania wobec pogranicza polsko-białoruskiego. Obszar Europy Wschodniej uzyskał inny charakter po rozszerzeniu Unii Europejskiej o Polskę, Litwę, Łotwę i Estonię. Granica polsko-białoruska stała się wschodnią granicą Unii Europejskiej. Procesy zachodzące na tym obszarze wykraczają poza ramy regulacji unijnej polityki transgraniczności. Kształtują się tam nowe relacje międzynarodowe i nowe normy wzajemnej współpracy oparte na wartościach cywilizacji europejskiej. Tereny pogranicza polsko-

${ }^{10}$ T. Konwicki, Kalendarz i klepsydra, Warszawa 1977, s. 115. 
-białoruskiego powinny być traktowane jako miejsce „wielkiego eksperymentu” w skali całej Unii Europejskiej. Na nich bowiem dochodzi do wielkiej promocji wartości europejskich, których filarami są państwo demokratyczne, gospodarka rynkowa, społeczeństwo obywatelskie, tolerancja, poszanowanie praw jednostki, ochrona praw mniejszości narodowych, etnicznych i religijnych, zachowanie dziedzictwa kulturowego. Doświadczenia historyczne pogranicza polsko-białoruskiego doskonale wpisują się w katalog wartości europejskich.

Rozwój Europy Wschodniej, a zwłaszcza terenów transgranicznych (Białorusi), zależy od funkcjonujących po obu stronach granicy uwarunkowań prawnych i ustrojowych oraz stopnia rozwoju instytucji demokratycznych. Zdefiniowanie tych uwarunkowań pozwala na przygotowanie projektów poszerzenia wzajemnych kontaktów i promocji wartości europejskich, m. in. poprzez ukazanie specyfiki polsko-białoruskiego pogranicza. Okazją do tego staje się Partnerstwo Wschodnie, które daje szansę na zbliżenie Białorusi do Unii Europejskiej. Istniejące dotąd bariery wynikają z odmiennego funkcjonowania systemu prawnego i społeczno-ekonomicznego mieszkańców Europy Wschodniej i bezpośrednio odnoszą się do relacji Unii Europejskiej z sąsiadującym z Unią państwem. Analiza procesów politycznych, społecznych, gospodarczych i kulturowych zachodzących na pograniczu polsko-białoruskim oraz wpływu granicy Unii Europejskiej na upowszechnianie się wartości europejskich na obszarach z nią sąsiadujących powinny stanowić wielkie wezwanie również dla współczesnych badaczy.

Badania naukowe pogranicza polsko-białoruskiego pozwolą poznać specyfikę historyczną i współczesne mechanizmy jego funkcjonowania oraz w lepszym stopniu zrozumieć zachodzące tam zmiany tożsamościowe i w samoidentyfikacji społecznej. Fakt ten daje możliwość ustalenia kierunków aktywności obszaru peryferyjnego Unii Europejskiej, szczególnie kapitału społecznego i kulturowego skupionego na obszarze transgranicza oraz pozwala wskazać perspektywy rozwojowe pogranicza polsko-białoruskiego w kontekście Partnerstwa Wschodniego. 